\title{
Book review: From the First World War to The Arab Spring: What's Really Going On in the Middle East?
}

\author{
Wai Yip Ho*
}

\author{
*Correspondence: \\ howaiyip@eduhk.hk \\ Department of Social \\ Sciences, Education \\ University of Hong Kong, 10 \\ Lo Ping Road, Tai Po, Hong \\ Kong SAR, China
}

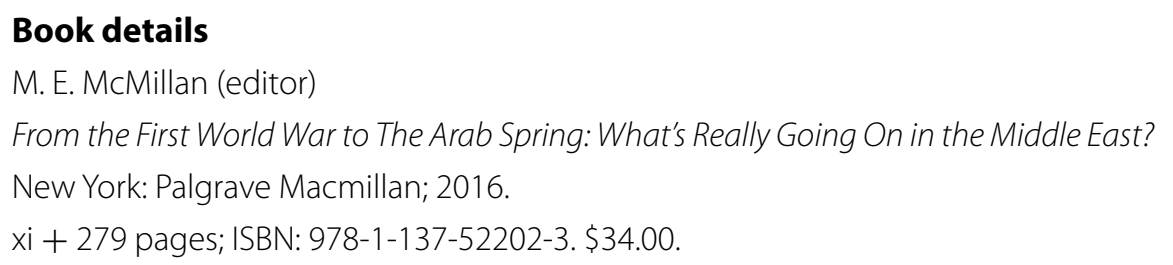

Attempting to comprehend what is really going on in the Middle East seems to be a daunting task for many people. M. E. McMillan's book accomplishes the seemingly impossible task of helping readers to make sense of the Middle East from World War One to the Arab Spring (from 1914 to the early 2010s) in an insightful and engaging manner. This widely acclaimed book successfully guides non-experts, with little intimidation, to understand the long-lasting historical causes of the unrest and crisis in the recent Middle East. McMillan demonstrates how re-telling history by linking current issues can be both entertaining and educational. As such, this book stimulates the beginner's appetite to approach the apparently inimical subject of the Middle East.

The author captivatingly begins her story with a single incident: Franz Urban's wrong turn in the streets of Sarajevo, which led to the killing of Franz Ferdinand and his wife on June 28, 1914 (Chapter 1). This event turned the history of Europe on its head and impacted the future of the Middle East. In closing her book, McMillan similarly explains how the singular tragedy of an ordinary Tunisian youth, Muhammad Bouazizi's selfimmolation in South Tunisia on Friday December 17, 2010, ignited the unstoppable flame of the uprisings across the Arab world. In one sense, McMillan stresses the unintended consequences of a single event, or how a decision made by an ordinary person can powerfully remake and shape the human future. The mechanistic view of historical inevitability, in particular the long-held conception of 'Arab Exceptionalism' in Middle East and Islamic and Arab studies is contested. McMillian rightly argues that what matters in the Arab world is the geopolitics and political economy (e.g., Stepan and Robertson 2004; Diamond 2010). The strength of the book is its emphasis on the future of the Arab democracy as an open-ended story shaped by various players and factors, thus

(c) The Author(s) 2018. This article is distributed under the terms of the Creative Commons Attribution 4.0 International License (http://creativecommons.org/licenses/by/4.0/), which permits unrestricted use, distribution, and reproduction in any medium, provided you give appropriate credit to the original author(s) and the source, provide a link to the Creative Commons license, and indicate if changes were made. 
rejecting the common pessimistic view that the lack of Arab democracy lies in the religion or culture of the region.

The book consists of five parts. In Part I, McMillan orients readers to rethink the seemingly chaotic situation of the Middle East as arising not totally from within. The region has been tangled in the power struggles between the Great Powers of Europe, and the region became a proxy theatre for the European power struggle after the First World War. According to McMillan, the entry of the Great Powers into the Middle East was not motivated by high political ideals but solely by Western strategic interests. Chapter 2 explains how the British Empire's strategic occupation of Egypt was intended to secure imperial interests in terms of geopolitics, while Chapter 3 argues that the French occupation of Algeria, Egypt, Lebanon and Tunisia was part of a civilizing mission to convert the people and land to a French way of life. While the Russian Empire's involvement in the Middle East was to defend Orthodox Christianity against the Ottoman Empire's threatening expansion (Chapter 4), the German Empire aimed to strengthen ties with Istanbul (Chapter 5). Once the Ottoman Empire went bankrupt after the Crimean War (Chapter 5), the collapse of the Ottomans unprecedentedly opened up the Middle East for remaking by the West (Chapter 6).

In Part II, McMillan guides readers to understand why the unnaturally straight national boundaries of the Middle East were the direct consequence of Anglo-French intervention after the demise of the Ottoman Empire and the abolition of the Caliphate. It was not only the map of the Middle East that was redrawn by the Sykes-Picot Agreement (Chapters 7-10); the Western intrusion also upset the region's long-standing communalism and tribal integration, resulting in far-reaching inter-ethnic tensions and sectarian conflicts. Further, the Treaty of Sèvres created new proxy states controlled by France and Britain and de-Islamized the public-political areas, but betrayed the Kurdish people without legitimate support for state-building (Chapter 11). In Part III, McMillan continues the tale of the Western remaking of the Middle East, which gave rise to the competing and controversial claims over the city of Jerusalem, which had long been highly revered and respected by Jewish people, Muslims and Christians (Chapter 12). In Chapter 13, the author ambitiously guides readers to understand how the conversion of the Roman Empire's Constantine sanctified Jerusalem as the city of Christ for Christian pilgrimage, but ironically laid the very first step of anti-Semitism by persecuting the Jews as Christ-killers. Moving from the Judeo-Christian perspective, Chapter 14 brings readers to consider the Islamic tale of Jerusalem. Reading this history of Jerusalem will surely help readers to make sense of the recent struggle between Palestinians and Israelis over US President Trump's decision to declare Jerusalem the capital city of Israel.

Having emphasized the openness and unpredictability of the Middle East's future, McMillan is not so naive as to neglect the deep power structures and cultural traditions that rigidly keep the Middle East in democratic deficit. In Part IV, McMillan explains how the monarchy (e.g., the Umayyad caliph Muawiya in the seventh century) and the military force (e.g., Colonel Gamal Abdel Nasser in Egypt) were two inertial structures that prevented Middle Eastern countries from transitioning from their medieval power structures to true freedom and democracy (Chapters 15-16). McMillan forcefully argues that different ruling families and military strongmen in the Middle East forsook the political framework based on Quranic principles in favor of power through hereditary 
succession, which is legitimized by the military authorities. This explains the deepseated frustrations of desperate youths living with social inequalities and no possibility of access to power, and the outbreak of protests and unrest in the contemporary Middle East. McMillan sharply criticizes the Western hypocrisy of colluding with the Middle East autocrats (Chapters 17-18). To further understand McMillan's ideas on the history of the Middle East, readers might find it useful to read her previous works (McMillan 2011, 2013). In Part V, McMillan explains that the contemporary dilemma in the Middle East is rooted in the question of Islamic authority: "Who can speak for Islam?" Tracing the formation of the Saudi family-Wahhabi alliance in the Kingdom of Saudi Arabia (Chapter 19) and the monopolization of power by religious clerics in the Islamic Republic of Iran (Chapter 20) explains the power structures of the two leading giants of the region, as well as the ongoing Sunni-Shiite sectarian divide (Chapter 21). In closing the book, the author reiterates the enduring importance of political Islam, pioneered by the Muslim Brotherhood in Egypt, in resisting the status quo of the one-party state, as young Muslims are ready to strive for the post-Arab Spring democratic alternative by speaking for themselves (Chapter 22 and Epilogue).

In short, the whole book skillfully contextualizes Middle Eastern affairs since the Arab Spring in the broader context of global history. McMillan effortlessly stimulates readers by retelling how a contingent event or one person's small decision has surprisingly altered and significantly sealed the fate of the Middle East from the outbreak of the First World War. While many are aware of the impossibility of understanding the present Middle East without a historical perspective, the main strength of this book is that it never gives readers the impression that history is boring or difficult so that they lose interest in learning about the past. Indeed, McMillan successfully weaves past events through interesting stories, attracting readers to listen to her excellent storytelling and gain the wisdom distilled from the lessons of history. While appreciating the author's effort in providing an objective historical analysis of the outbreak of the Arab Spring, however, this book has its weaknesses. It does not provide an analysis to make sense of the spontaneous emergence of uprisings and the possibility of a democratic Arab future. To overcome the weaknesses, the book requires a more detailed analysis of the recent causes of the Arab Spring and beyond. To complement McMillan's study, several unexpected and new elements of future democratic development in the Middle East should be covered. Shared by scholars in the Middle Eastern Studies (e.g., Sadiki 2015), McMillan rightly stresses the Arab Spring as a bottom-up youth movement, and young people as major actors and agents of bottom-up change for the Arab world. But the book fails to unfold the young generation's growing demands for an end to corruption and authoritarian rule, the right to free expression, the end of restrictions on citizens' political rights and the failure to implement liberalizing economic reforms (e.g., Rand 2013). It does not address the power of social media in enabling young people to express their outrage and hope beyond the traditional control of power structures, so that rapid mobilization can emerge off-line (e.g. Castells 2015). Nor does it consider the post-Islamists' call for reform, not fundamental revolution, directed through civil, non-religious groups, frontier women's groups and the Islamists parties (e.g., Bayat 2017; Esposito et al. 2015; Mandaville 2014). While some scholars have been optimistic in viewing the Arab Spring as inaugurating a new era of postcolonial thinking about the Middle East (e.g., Dabashi 2012), some puzzles remain unanswered. For example, why has regime change taken place only in some countries (Tunisia, Egypt, Yemen and Libya) and democratization in others (Tunisia and 
Morocco), while in some countries there has been a complete absence of uprisings (e.g., Algeria and Saudi Arabia), an increase of authoritarianism (e.g., Turkey, Bahrain and Kuwait) and even further fragmentation and civil war in others (e.g., Libya and Syria) (e.g. Browlee et al. 2015; Szmolka 2017)? Unfortunately, readers will not find the answers to these questions in McMillan's book.

Nevertheless, From the First World War to The Arab Spring: What's Really Going On in the Middle East? remains an invaluable addition to the field of Middle East Studies and democratization studies. Beyond the specialized field of Middle Eastern studies, the unique contribution of this book should also be of interest to scholars in the field of the Global South. The contemporary situation in the Global South is not entirely generated from within, but must be interpreted in light of the colonial past and the historical interaction with the Global North. In addition, McMillan provides a timely reminder that the historical contingency initiated by human agency and the rigidity of social structures constituted by cultural traditions are both important in explaining what is really going on in the Global South.

\section{Authors' contributions}

The author read and approved the final manuscript.

\section{Acknowledgements}

I am indebted to my wife Pang Ping Yuen Ivy and daughter Ho King Min Noel for their patience during my fieldwork outside home. And I have to acknowledge the great research environment and support from Freiburg Institute for Advanced Studies (FRIAS), in particular I am thankful to the kindness of Professor Bernd Kortmann, Dr. Carsten Dose, Dr. Britta Küst, Helen Pert, Petra Fischer and Nikolaus Binder.

\section{Competing interests}

The author declares no competing interests.

\section{Availability of data and materials}

Not applicable.

Ethics approval and consent to participate

Not applicable.

\section{Funding}

The research leading to these results has received funding from the People Program (Marie Curie Actions) of the European Union's Seventh Framework Programme (FP7/2007-2013) under REA Grant Agreement No (609305).

\section{Publisher's Note}

Springer Nature remains neutral with regard to jurisdictional claims in published maps and institutional affiliations.

Received: 14 February 2018 Accepted: 25 May 2018

Published online: 01 June 2018

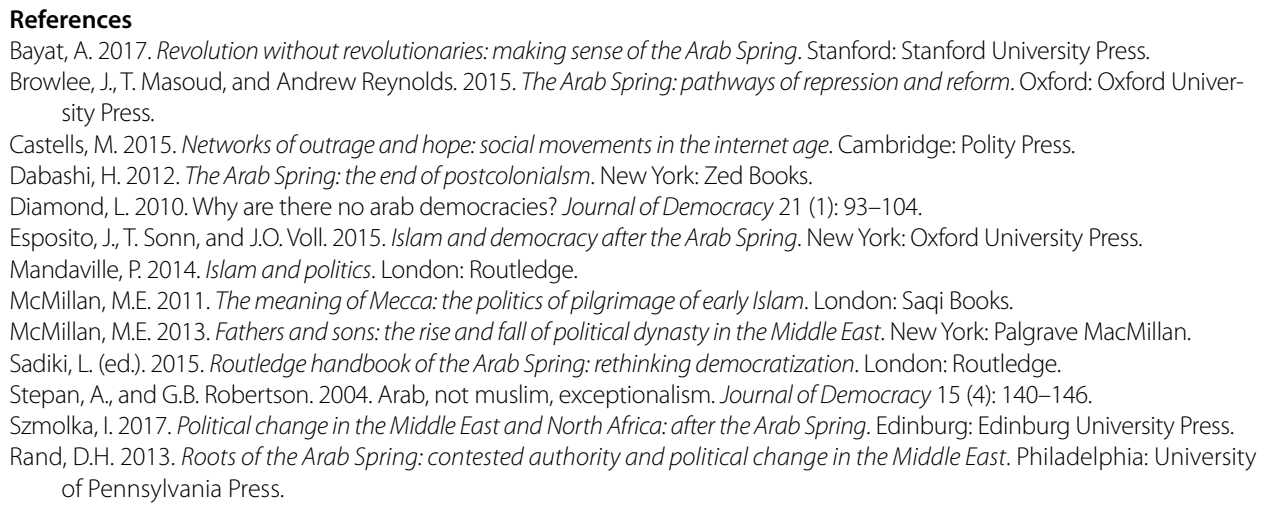

